\title{
PERANCANGAN DAN ANALISA SISTEM KENDALI FREKUENSI SISTEM TENAGA LISTRIK DENGAN METODE PENEMPATAN KUTUB
}

\author{
Heru Dibyo Laksono ${ }^{1}$ \\ Aditya Putra Pratama ${ }^{2}$
}

\begin{abstract}
This study discusses the application of Polar Placement method using Bass Gura algorithm on Non - Reheat type frequency electric control system with emphasis on frequency deviation on power system. The performance indicators of electric power system that can be calculated and observed include error analysis, response speed, response quality, frequency domain analysis, stability analysis and robustness analysis of the frequency deviation response of electric power system. The simulation results show that the non-reheat type deviation of electric power with Polar Placement method shows better result compared to non-reheat type frequency power deviation response without the Polar Placement method with a steady state error value of 0.0041 , the rise time value of 0.0562 second, the peak time value is 0.0049 seconds, the time value of the steady state is 0.5113 seconds, the maximum pass value is $19.2112 \%$, the root of the characteristic equation which all the parts are negative, the maximum peak value is 1.0049 and the maximum peak value of complementary sensitivity is 0.0051 .
\end{abstract}

Keywords: Frequency Deviation, Polar Placement, Bass - Gura Algorithm, Non Reheat

\section{INTI SARI}

Penelitian ini membahas tentang aplikasi metoda Penempatan Kutub menggunakan algoritma Bass - Gura pada sistem kendali frekuensi tenaga listrik tipe Non - Reheat dengan penekanan pada deviasi frekuensi pada sistem tenaga listrik. Adapun indikator performansi sistem tenaga listrik yang bisa dihitung dan diamati diantaranya analisa kesalahan, kecepatan tanggapan, kualitas tanggapan, analisa domain frekuensi, analisa kestabilan dan analisa kekokohan dari tanggapan deviasi frekuensi sistem tenaga listrik. Hasil simulasi memperlihatkan bahwa tanggapan deviasi frekuensi tenaga listrik tipe non reheat dengan metoda Penempatan Kutub memperlihatkan hasil yang lebih baik dibandingkan dengan tanggapan deviasi frekuensi tenaga listrik tipe non reheat tanpa metoda Penempatan Kutub dengan nilai kesalahan keadaan mantap sebesar 0.0041, nilai waktu naik sebesar 0.0562 detik, nilai waktu puncak sebesar 0.0049 detik, nilai waktu keadaan mantap sebesar 0.5113 detik, nilai lewatan maksimum sebesar $19.2112 \%$, akar - akar persamaan karakteristik yang semua bagian nyatanya bernilai negatif, nilai puncak maksimum sebesar 1.0049 dan nilai puncak maksimum sensitivitas komplementer sebesar 0.0051 .

Kata Kunci: Deviasi Frekuensi, Penempatan Kutub ,Algoritma Bass - Gura, Non - Reheat

$\overline{1,2}$ Jurusan Teknik Elektro Fakultas Teknik Universitas Andalas 


\section{PENDAHULUAN}

Sistem yang digunakan untuk menjaga deviasi frekuensi tenaga listrik yang ditimbulkan oleh perubahan beban terutama pada saat pembagian beban yang harus dipikul oleh sebuah generator dikenal sebagai sistem kendali frekuensi tenaga listrik. Pusat pusat pembangkit harus dapat memenuhi kebutuhan beban yabg berubah - ubah. Adapun masalah yang sering muncul dalam operasi sistem tenaga listrik dimana daya yang dibangkitkan atau yang diproduksi selalu sama dengan daya yang dikosumsi oeh konsumen tenaga listrik. Perubahan beban yang mendadak membawa dampak negatif terhadap performansi sistem tenaga listrik secara keseluruhan [1]. Adapun indikator performansi sistem tenaga listrik yang diamati diantaranya analisa kesalahan, kecepatan tanggapan, kualitas tanggapan, analisa domain frekuensi, analisa kestabilan dan analisa kekokohan dari tanggapan deviasi frekuensi sistem tenaga listrik tersebut.

Berbagai usaha dengan berbagai metoda sudah dilakukan untuk memperbaiki performansi tanggapan deviasi frekuensi sistem tenaga listrik akibat perubahan beban diantaranya metoda logika fuzzy dan kendali konvensional dengan pengendali Integral [2]. Jurnal ini membahas tentang analisa performansi sistem kendali frekuensi tenaga listrik tipe satu masukan satu keluaran dalam domain waktu untuk tipe Non Reheat. Metoda Linear Quadratic Regulator (LQR) [3]. Pembahasan pada jurnal ini meliputi analisa peralihan sistem kendali frekuensi tenaga listrik untuk tipe Non Reheat. Dengan pengendali Proporsional Integral Diferensial (PID) Optimal [4]. Adapun pembahasan dalam jurnal ini ditekankan pada analisa peralihan sistem kendali frekuensi tenaga listrik dalam domain waktu untuk tipe Non - Reheat. Dengan pengendali Integral (I), pengendali Proporsional Integral (PI) dan pengendali Proporsional Integral Diferensial (PID) [5]. Pembahasan pada jurnal ini juga ditekankan pada analisa peralihan sistem kendali frekuensi tenaga listrik dalam domain waktu untuk tipe Non - Reheat. Dengan metoda optimal, adapun pembahasan pada jurnal ini meliputi analisa peralihan deviasi frekuensi sistem kendali frekuensi tenaga listrik dengan metoda Linear Quadratic Regulator (LQR) dan metoda Linear Quadratic Regulator dengan fungsi bobot pada keluaran (LQRy) untuk tipe Non Reheat, Reheat dan Hidraulik [6]. Selanjutnya pada jurnal ini ditekankan pada analisa kesalahan, kecepatan dan kualitas tanggapan, analisa performansi dalam domain frekuensi, analisa kestabilan dan analisa kekokohan dari tanggapan deviasi frekuensi sistem tenaga listrik tipe Non Reheat.

Hasil analisa pendahuluan untuk tanggapan deviasi frekuensi sistem tenaga listrik tipe Non Reheat memperlihatkan kecepatan dan kualitas tanggapan yang kurang memuaskan terutama untuk waktu puncak, waktu keadaan mantap dan lewatan maksimum Selain itu performansi dalam domain frekuensi dari deviasi frekuensi Tenaga listrik juga kurang mmemuaskan juga terutama untuk nilai lebar pita yang masih kecil sedangkan untuk analisa kesalahan, analisa kestabilan dan analisa kekokohan dari tanggapan deviasi frekuensi sistem tenaga listrik tipe Non - Reheat sudah memuaskan. Selanjutnya pada penelitian ini akan dilakukan perancangan dan analisa sistem kendali frekuensi tenaga listrik tipe Non - Reheat menggunakan metoda Penempaatan Kutub dengan algoritma Bass - Gura. Penggunaan 
metoda Bass - Gura ini dikarenakan dengan metoda Penempatan Kutub menggunakan algoritma Baa - Gura ini tanggapan deviasi frekuensi sistem tenaga listrik dijamin bersifat stabil dan kokoh terhadap gangguan, mempuai kemapuan untuk meredam derau pada frekuensi tinggi serta mempuyai tanggapan yang cepat terhadap masukan tertentu.

Hasil dari penelitian ini diharapkan nantinya diperoleh informasi mengenai kesalahan, kecepatan dan kualitas tanggapan, performansi dalam domain frekuensi, kestabilan dan kekokohan dari tanggapan deviasi frekuensi sistem tenaga listrik tipe Non Reheat. Agar diperoleh hasil penelitian sesuai yang diharapkan maka pembahasan penelitian ini dibatasi sebagai berikut

1. Model sistem kendali frekuensi tenaga listrik bersifat linier, tak berubah terhadap waktu dan kontinu.

2. Sistem kendali frekuensi tenaga listrik bersifat satu masukan satu keluaran.

3. Analisa dilakukan dengan bantuan perangkat lunak Matlab.

Untuk sistematika penulisan jurnal ini terdiri pendahuluan, tinjuan pustaka, metodologi penelitian, hasil dan pembahasan, kesimpulan serta diakhiri dengan daftar pustaka.

\section{PENDEKATAN DAN PEMECAHAN MASALAH}

Pada bagian ini dibahas tentang pemodelan sistem kendali frekuensi tenaga listrik tipe Non Reheat, metoda Penempatan Kutub dengan algoritma Bass - Gura serta analisa sistem kendali deviasi frekuensi sistem tenaga listrik. Untuk pemodelan, tipe sistem kendali frekuensi tenaga listrik yang digunakan adalah tipe Non Reheat.

\section{Pemodelan Tipe Sistem Kendali Frekuensi Tenaga Listrik}

Model tipe sistem kendali frekuensi tenaga listrik yang dibahas pada bagian ini adalah model sistem kendali sistem tenaga listrik tipe Non - Reheat. Model sistem kendali frekuensi tenaga listrik ini dinyatakan dalam bentuk diagram blok serta direpresentasikan dalam bentuk persamaan keadaan. Untuk diagram blok sistem kendali frekuensi tenaga listrik tipe Non Reheat diperlihatkan pada Gambar 1 berikut.

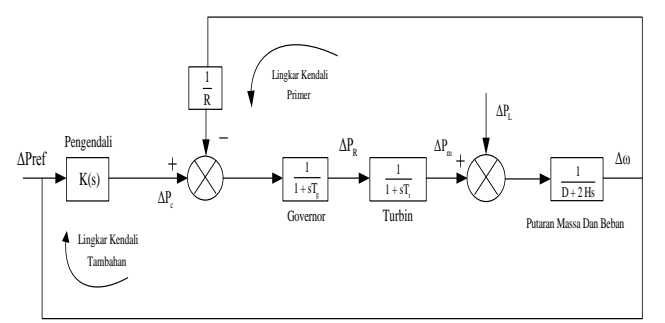

Gambar 1. Diagram Blok Sistem Kendali Frekuensi Tenaga Listrik Tipe Non - Reheat [1]

Penjelasan masing - masing blok pada Gambar 1 bisa dilihat pada referensi [1]. Untuk parameter parameter dari diagram blok sistem kendali frekuensi tenaga listrik model Non - Reheat diperlihatkan pada Tabel 1 berikut [1]

Tabel 1. Parameter - Parameter Sistem Kendali Frekuensi Tenaga Listrik Model Non - Reheat

\begin{tabular}{|c|c|}
\hline Parameter & Nilai \\
\hline $\mathrm{T}_{\mathrm{g}}$ & 0.2000 detik \\
\hline $\mathrm{T}_{\mathrm{t}}$ & 0.5000 detik \\
\hline $\mathrm{H}$ & 5.0000 detik \\
\hline $\mathrm{R}$ & $0.0500 \mathrm{~Hz} / \mathrm{pu}(\mathrm{MW})$ \\
\hline $\mathrm{D}$ & $0.8000 \mathrm{pu} \mathrm{MW/Hz}$ \\
\hline
\end{tabular}

Dengan bantuan perangkat lunak Matlab, nilai - nilai parameter sistem kendali frekuensi tenaga listrik model Non - Reheat pada Tabel 1 disubstitusi ke diagram blok pada 
Gambar 1 dan diperoleh persamaan keadaan (1) dan (2) berikut

$$
\begin{aligned}
& \dot{\mathrm{x}} \mathrm{t}=\mathrm{Ax} \mathrm{t}+\mathrm{Bu} \mathrm{t} \\
& \mathrm{y} \mathrm{t}=\mathrm{Cx} \mathrm{t}
\end{aligned}
$$

dimana

$$
\mathrm{A}=\left[\begin{array}{ccc}
-5.0000 & 0.0000 & -100.0000 \\
2.0000 & -2.0000 & 0.0000 \\
0.0000 & 0.1000 & -0.0800
\end{array}\right]
$$

(3)

$$
\begin{aligned}
& \mathrm{B}=\left[\begin{array}{c}
0.0000 \\
0.0000 \\
-0.1000
\end{array}\right] \quad(4) \\
& \mathrm{C}=\left[\begin{array}{lll}
0.0000 & 0.0000 & 1.0000
\end{array}\right](5)
\end{aligned}
$$

\section{Metoda Penempatan Kutub} Dengan Algoritma Bass - Gura Metode penempatan kutub itu didasari berdasarkan suatu masukan kendalian $\mathrm{u}(\mathrm{t})$ yang merupakan suatu fungsi keadaan dimana $\mathrm{x}(\mathrm{t})$ merupakan sinyal umpan balik dalam bentuk persamaan (6) berikut

$\mathrm{u} t=\mathrm{f} \times \mathrm{t}$

Persamaan (6) disebut hukum kendali. Dalam perancangan sistem kendali dengan metoda penempatan kutub, hukum kendali dinyatakan dalam bentuk persaman (7) berikut

$$
\mathrm{u} \mathrm{t}=\mathrm{Kx} \mathrm{t}
$$

Dimana $\mathrm{K}$ adalah sebuah vektor penguatan konstan yang mempuyai dimensi $1 \times$ u. Hukum kendali pada persamaan (6) mengizinkan seluruh kutub dari sistem lingkar tertutup untuk ditempatkan disembarang tempat yang dikehendaki. Selain itu persamaan (7) dapat juga dikembangkan menjadi persamaan (8) berikut $\mathrm{ut}=-\mathrm{K}_{1} \mathrm{x}_{1} \mathrm{t}-\mathrm{K}_{2} \mathrm{x}_{2} \mathrm{t} \ldots \mathrm{K}_{\mathrm{n}} \mathrm{x}_{\mathrm{n}} \mathrm{t}$ (8)
Nilai $\mathrm{K}_{1}, \mathrm{~K}_{2, \ldots \ldots . .,} \mathrm{K}_{\mathrm{n}}$ dihitung dengan menggunakan algoritma Bass Gura. Pada algoritma Bass Gura diasumsikan kutub - kutub lingkar tertutup dinyatakan dalam bentuk $\mu_{i}$ dimana $i=1,2,3, \ldots . ., n$ dan persamaan karakteristik lingkar tertutup dinyatakan dalam bentuk persamaan (9) berikut

$\alpha s=\prod_{i=1}^{n} s-\mu_{i}=s^{n}+\alpha_{1} s^{n-1}+\alpha_{2} s^{n-2}+\ldots+\alpha_{n-1} s+\alpha_{n}$

Untuk persamaan karakteristik lingkar terbuka dinyatakan dalam bentuk persamaan (10) berikut

a $\mathrm{s}=\operatorname{det} \mathrm{sI}-\mathrm{A}=\mathrm{s}^{\mathrm{n}}+\mathrm{a}_{1} \mathrm{~s}^{\mathrm{n}-\mathrm{1}}+\mathrm{a}_{2} \mathrm{~s}^{\mathrm{n}-2}+\ldots+\mathrm{a}_{\mathrm{n}-\mathrm{1}} \mathrm{s}+\mathrm{a}_{\mathrm{n}}$

Umpan balik vektor $\mathrm{K}$ dinyatakan dalam bentuk persamaan (11) berikut

$$
\mathrm{K}=[\mathrm{a}-\alpha]^{\mathrm{T}} \mathrm{L}^{-1} \hat{\mathrm{C}}^{-1}
$$

Dimana

$\mathrm{K}$ : penguatan dengan algoritma

$$
\text { Bass - Gura }
$$

$\hat{\mathrm{C}}^{-1}$ : matrik controllable

L : : matrik Hankel non - singular

Berdasarkan persamaan (11) dapat diturunkan persamaan (12), (13) dan (14) berikut

$[a-\alpha]^{\mathrm{T}}=\left[\begin{array}{lll}a_{1}-\alpha_{1} & \ldots & a_{n}-\alpha_{n}\end{array}\right]$

$$
\hat{C}=\left[B, A B, \ldots, A^{n-1} B\right]
$$


$\mathrm{L}=\left[\begin{array}{ccccc}\mathrm{a}_{\mathrm{n}-1} & \mathrm{a}_{\mathrm{n}-2} & \ldots & \mathrm{a}_{1} & 1 \\ \mathrm{a}_{\mathrm{n}-2} & \mathrm{a}_{\mathrm{n}-3} & \ldots & 1 & \\ \vdots & \vdots & & & \\ \mathrm{a}_{1} & 1 & & & \\ 1 & & & & \end{array}\right]$

(14)

Setelah didapatkan nilai $K$ berdasarkan persamaan (11), maka selanjutnya akan di dapatkan lagi nilai fungsi alih yang baru.

\section{Analisa Sistem Kendali Deviasi Frekuensi Tenaga Listrik}

Bagian ini menjelaskan analisa sistem kendali deviasi frekuensi tenaga listrik. Analisa yang dilakukan meliputi analisa kesalahan, kecepatan dan kualitas tanggapan, analisa performansi dalam domain frekuensi, analisa kestabilan dan analisa kekokohan. Untuk analisa kesalahan, parameter yang diamati adalah nilai kesalahan keadaan mantap [8]. Untuk kecepatan tanggapan, parameter yang diamati terdiri waktu naik, waktu puncak dan waktu keadaan mantap sedangkan untuk kualitas tanggapan ditunjukkan oleh lewatan maksimum [9]. Untuk analisa performansi dalam domain frekuensi, parameter yang diamati meliputi margin penguatan dan lebar pita sedangkan untuk analisa kekokohan parameter yang diamati nilai puncak sensitivitas dan nilai puncak sensitivitas komplementer [7].

\section{METODOLOGI PENELITIAN}

Pemodelan matematis sistem kendali frekuensi tenaga listrik merupakan langkah awal dalam penelitian ini. Model sistem kendali frekuensi tenaga listrik yang dibahas model sistem kendali frekuensi tenaga listrik tipe Non - Reheat. Elemen - elemen yang dibahas dalam pemodelan matematis sistem kendali frekuensi tenaga listrik ini meliputi pemodelan turbin, pemodelan governor, pemodelan beban dan pemodelan generator. Pemodelan matematis sistem kendali frekuensi tenaga listrik ini dilakukan dengan menggunakan persamaan linear diferensial dan transformasi Laplace. Hasil pemodelan masing - masing komponen ini berupa fungsi alih orde satu. Fungsi alih dari masing-masing komponen ini kemudian digabungkan dan diperoleh fungsi alih sistem kendali frekuensi tenaga listrik. Fungsi alih sistem kendali frekuensi tenaga listrik ini kemudian diubah menjadi persamaan keadaan dengan bantuan perangkat lunak Matlab. Untuk persamaan keadaan sistem kendali frekuensi tenaga listrik tipe Non - Reheat diperlihatkan pada persamaan (1) $\mathrm{s} / \mathrm{d}$ (5). Adapun keluaran dari sistem kendali frekuensi tenaga listrik adalah deviasi frekuensi dan masukannya adalah perubahan beban.

Selanjutnya dilakukan analisa sistem kendali deviasi frekuensi tenaga listrik. Analisa yang dilakukan terdiri analisa kesalahan, kualitas dan kecepatan tanggapan, analisa performansi dalam domain frekuensi, analisa kestabilan dan analisa kekokohan. Untuk analisa kesalahan, parameter yag diamati adalah nilai kesalahan keadaan mantap dari tanggapan deviasi frekuensi tenaga listrik. Untuk kecepatan tanggapan, parameter yang diamati terdiri waktu naik, waktu puncak dan waktu keadaan mantap dari tanggapan deviasi frekuensi tenaga listrik sedangkan untuk kualitas tanggapan ditunjukkan oleh lewatan maksimum dari tanggapan deviasi frekuensi 
tenaga listrik. Untuk analisa kestabilan dari tanggapan deviasi frekuensi tenaga listrik dilakukan dengan menggunakan metoda akar - akar persamaan karakteristik. Tanggapan deviasi frekuensi tenaga listrik akan bersifat stabil jika bagian nyata dari akar - akar persamaan karakteristik bernilai negatif. Bagian akhir analisa yang dilakukan adalah analisa kekokohan. Analisa kekokohan dilakukan dengan menghitung nilai sensitivitas dan nilai sensitivitas komplementer dari tanggapan deviasi frekuensi tenaga listrik.. Berdasarkan hasil analisa kemudian ditentukan kriteria perancangan pengendali. Adapun kriteria perancangan yang diinginkan meliputi waktu naik kurang dari 0.5000 detik, waktu keadaan mantap kurang dari 1.0000 detik, waktu puncak kurang dari 1.2500 , lewatan maksimum kurang dari $20.0000 \%$, nilai kesalahan keadaan mantap kurang dari 0.0500 , lebar pita kurang dari 15.0000 $\mathrm{rad} /$ detik, nilai puncak maksimum kurang dari $2.0000(6 \mathrm{~dB})$ dan nilai puncak maksimum sensitivitas komplementer kurang dari 1.2500 (2 $d B)$.

Selanjutkan dilakukan
perancangan pengendali untuk
sistem kendali frekuensi tenaga
listrik dengan menggunakan metoda
Penempatan Kutub dengan
menggunakan algoritma Bass Gura. Hasil perancangan pengendali berupa persamaan keadaan pengendali. Persamaan keadaan pengendali kemudian digabungkan dengan persamaan keadaan dari sistem kendali frekuensi tenaga listrik tipe Non - Reheat sehingga diperoleh persamaan keadaan baru untuk sistem kendali frekuensi tenaga listrik. Selanjutnya dilakukan analisa dari tanggapan deviasi frekuensi sistem kendali frekuensi tenaga listrik dengan metoda Penempatan Kutub menggunakan algoritma Bass - Gura. Informasi yang diperoleh sama dengan informasi analisa dari tanggapan dviasi frekuensi sistem kendali frekuensi tenaga listrik tanpa metoda Penempatan Kutub.

\section{HASIL DAN PEMBAHASAN}

Pada bagian ini diperlihatkan hasil dan pembahasan mengenai tanggapan deviasi frekuensi tenaga listrik tanpa dan dengan metoda Penempatan Kutub menggunakan algoritma Bass - Gura. Pembahasan yang dilakukan meliputi analisa kesalahan yang terdiri dari analisa kesalahan keadaan mantap mantap, analisa kecepatan tanggapan yang ditunjukkan oleh waktu naik, waktu puncak dan waktu keadaan mantap. Analisa kualitas tanggapan ditunjukkan oleh nilai lewatan maksimum. Untuk analisa performansi dalam domain frekuensi ditunjukkan oleh lebar pita, untuk analisa kestabilan dilakukan dengan melihat posisi dari nilai bagian nyata dari dari persamaan karakterstik. Sistem akan bersifat stabil jika nilai bagian nyata dari persamaan karakteristik itu bernilai negatif. Untuk analisa kekokohan ditunjukkan oleh nilai puncak sensitivitas dan nilai puncak senstivitas komplementer.

Untuk nilai kesalahan mantap dari tanggapan deviasi frekuensi sistem tenaga listrik tipe Non Reheat tanpa metoda Penempatan Kutub diperlihatkan pada Tabel 2 . berikut

Tabel 1. Nilai Kesalahan Keadaan Mantap

\begin{tabular}{|l|c|}
\hline \multicolumn{1}{|c|}{ Kriteria } & Nilai \\
\hline $\begin{array}{l}\text { Nilai } \quad \begin{array}{l}\text { Kesalahan } \\
\text { Keadaan Mantap }\end{array} \\
\text { Keanta }\end{array}$ & 0.0481 \\
\hline
\end{tabular}


Untuk informasi kualitas dan kecepatan dari tanggapan deviasi frekuensi sistem tenga listrik tipe Non - Reheat tanpa metoda Penempatan Kutub diperlihatkan oleh tanggapan peralihan deviasi frekuensi sistem tenaga listrik. Adapun informasi yang diperoleh diperlihatkan pada Tabel 3. berikut
Tabel 3. Informasi Analisa Peralihan

\begin{tabular}{|l|c|}
\hline \multicolumn{1}{|c|}{ Parameter } & Nilai \\
\hline Waktu Naik & 0.4135 detik \\
\hline $\begin{array}{l}\text { Waktu Keadaan } \\
\text { mantap }\end{array}$ & 6.8143 detik \\
\hline Waktu Puncak & 1.2345 detik \\
\hline $\begin{array}{l}\text { Lewatan } \\
\text { Maksimum }\end{array}$ & $54.7868 \%$ \\
\hline
\end{tabular}

Tanggapan peralihan deviasi frekuensi sistem kendali frekuensi tenaga listrik untuk tipe Non Reheat terhadap masukan undak satuan diperlihatkan pada Gambar 2. berikut



Gambar 2. Tanggapan Peralihan Deviasi Frekuensi Untuk Tipe NonReheat

Untuk analisa performansi dalam domain frekuensi diperlihatkan oleh nilai lebar pita. Untuk nilai lebar pita diperoleh dari diagram Magnitude Bode tanggapan deviasi frekuensi sistem tenaga listrik tipe Non Reheat. Adapun nilai lebar pita diperlihatkan pada Tabel 4. berikut
Tabel 4. Hasil Analisa Performansi Dalam Domain Frekuensi

\begin{tabular}{|l|c|}
\hline \multicolumn{1}{|c|}{ Kriteria } & Nilai \\
\hline Lebar Pita & $3.6959 \mathrm{rad} /$ detik \\
\hline
\end{tabular}

Untuk diagram Magnitude Bode tanggapan deviasi frekuensi sistem tenaga listrik tipe Non - Reheat diperlihatkan pada Gambar 3. berikut 


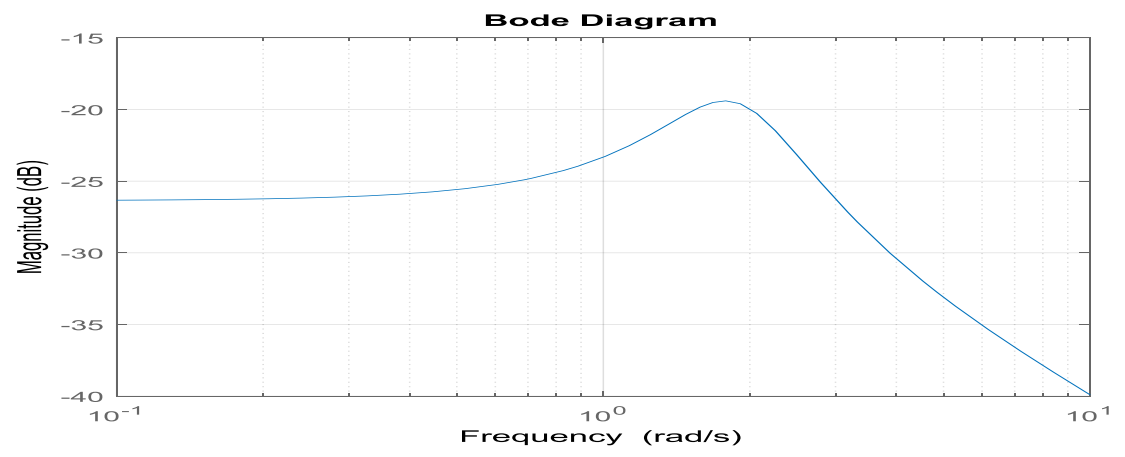
Gambar 3. Diagram Magnitude Bode Deviasi Frekuensi Sistem Tenaga
Listrik Tipe Non - Reheat

Untuk analisa kestabilan deviasi frekuensi sistem tenaga listrik tipe Non - Reheat dilakukan dengan menggunakan persamaan karakteristik. Adapun akar - akar dari persamaan karakteristik ini diperlihatkan pada Tabel 5. berikut

Tabel 5. Akar - Akar Persamaan Karakteristik

\begin{tabular}{|c|c|c|c|}
\hline $\begin{array}{l}\text { Akar - } \\
\text { Akar }\end{array}$ & $\begin{array}{c}\text { Redama } \\
\mathrm{n}\end{array}$ & $\begin{array}{c}\text { Frekuen } \\
\text { si }\end{array}$ & $\begin{array}{l}\text { Konstant } \\
\text { a Waktu }\end{array}$ \\
\hline $\begin{array}{l}- \\
0.597 \\
0+ \\
j 1.780 \\
0\end{array}$ & 0.3180 & 1.8800 & 1.6800 \\
\hline $\begin{array}{l}- \\
0.597 \\
0+ \\
j 1.780 \\
0\end{array}$ & 0.3180 & 1.8800 & 1.6800 \\
\hline $\begin{array}{l}- \\
5.890 \\
0\end{array}$ & 1.0000 & 5.8900 & 0.1700 \\
\hline
\end{tabular}

Untuk analisa kekokohan tanggapan deviasi frekuensi sistem tenaga listrik tipe Non - Reheat dilakukan dengan menggunakan nilai puncak sensitivitas dan nilai puncak sensitivitas komplementer. Adapun kedua nilai sensitivitas dari tanggapan deviasi frekuensi sistem tenaga listrik tipe Non - Reheat diperlihatkan pada Tabel 6. Berikut
Tabel 6. Hasil Analisa Performansi Dalam Domain Frekuensi

\begin{tabular}{|l|c|}
\hline \multicolumn{1}{|c|}{ Kriteria } & Nilai \\
\hline $\begin{array}{l}\text { Nilai Puncak Maksimum } \\
\text { Sensitivitas }\end{array}$ & 1.0961 \\
\hline $\begin{array}{l}\text { Nilai Puncak Maksimum } \\
\text { Sensitivitas } \\
\text { Komplementer }\end{array}$ & 0.1072 \\
\hline
\end{tabular}

Untuk hasil simulasi tanpa metoda Penempatan Kutub dibandingkan dengan kriteria perancangan diperoleh informasi untuk nilai kesalahan keadaan mantap, nilai waktu naik, nilai waktu puncak, nilai puncak maksimum serta nilai puncak maksimum sensitivitas serta nilai akar - akar persamaan karakteristik sudah memenuhi kriteria perancangan sedangkan untuk nilai waktu keadaan mantap, nilai lewatan maksimum dan nilai lebar belum memenuhi kriteria perancangan

Selanjutnya dilakukan perancangan pengendali untuk sistem kendali deviasi frekuensi tenaga listrik dengan metoda Penempatan Kutub menggunakan algoritma Bass Gura. Untuk menggunakan metoda Penempatan Kutub dengan menggunakan algoritma Bass Gura ini terlebih dahulu ditentukan nilai pergeseran kutub. Nilai pergeseran kutub ini ditentukan secara berulang - ulangagar tanggapan deviasi frekuensi tenaga listrik ini sesuai dengan yang 
diinginkan. Adapun nilai pergeseran pole ini diperlihatkan pada persamaan (15) berikut

$$
\mathrm{P}=-11.7640 \quad-10.3880 \quad-1.9970
$$

dan nilai penguatan yang diperoleh dengan menggunakan algoritma Bass - Gura diperlihatkan pada persamaan (16) berikut

$\mathrm{K}=3.6399 \quad-1.0123 \quad-170.6900$

Persamaan (16) ini kemudian disubstitusikan ke persamaan (1) dan (2) diperoleh persamaan (17) dan (18) berikut

$$
\begin{aligned}
& \dot{\mathrm{x}} \mathrm{t}=\mathrm{Ax} \mathrm{t}+\mathrm{Bu} \mathrm{t} \\
& \mathrm{y} \mathrm{t}=\mathrm{Cx} \mathrm{t}
\end{aligned}
$$

dimana

$$
\begin{aligned}
& A=\left[\begin{array}{ccc}
-5.0000 & 0.0000 & -100.0000 \\
2.0000 & -2.0000 & 0.0000 \\
0.3640 & -0.0012 & -17.1500
\end{array}\right] \\
& B=\left[\begin{array}{c}
0.0000 \\
0.0000 \\
-0.1000
\end{array}\right] \\
& C=\left[\begin{array}{lll}
0.0000 & 0.0000 & 1.0000
\end{array}\right](21)
\end{aligned}
$$

$$
\text { Selanjutnya dengan }
$$
menggunakan persamaan (17) s/d (21) dilakukan analisa yang sama dengan analisa tanggapan deviasi frekuensi sistem tenaga listrik tanpa metoda Penempatan Kutub dengan menggunakan algoritma Bass Gura. Untuk nilai kesalahan mantap dari tanggapan deviasi frekuensi sistem tenaga listrik tipe Non Reheat dengan metoda Penempatan Kutub diperlihatkan pada Tabel 7 . berikut
Tabel 7. Nilai Kesalahan Keadaan Mantap

\begin{tabular}{|l|c|}
\hline \multicolumn{1}{|c|}{ Kriteria } & Nilai \\
\hline $\begin{array}{l}\text { Nilai } \quad \text { Kesalahan } \\
\text { Keadaan Mantap }\end{array}$ & 0.0041 \\
\hline
\end{tabular}

Untuk informasi kualitas dan kecepatan dari tanggapan deviasi frekuensi sistem tenga listrik tipe Non - Reheat dengan metoda Penempatan Kutub diperlihatkan oleh tanggapan peralihan deviasi frekuensi sistem tenaga listrik. Adapun informasi yang diperoleh diperlihatkan pada Tabel 8 . berikut

Tabel 8. Informasi Analisa Peralihan

\begin{tabular}{|l|c|}
\hline \multicolumn{1}{|c|}{ Parameter } & Nilai \\
\hline Waktu Naik & 0.0562 detik \\
\hline $\begin{array}{l}\text { Waktu Keadaan } \\
\text { mantap }\end{array}$ & 0.5113 detik \\
\hline Waktu Puncak & 0.0049 detik \\
\hline $\begin{array}{l}\text { Lewatan } \\
\text { Maksimum }\end{array}$ & $19.2112 \%$ \\
\hline
\end{tabular}

Tanggapan peralihan deviasi frekuensi sistem kendali frekuensi tenaga listrik untuk tipe Non Reheat dengan metoda Penempatan Kutub terhadap masukan undak satuan diperlihatkan pada Gambar 4. berikut 


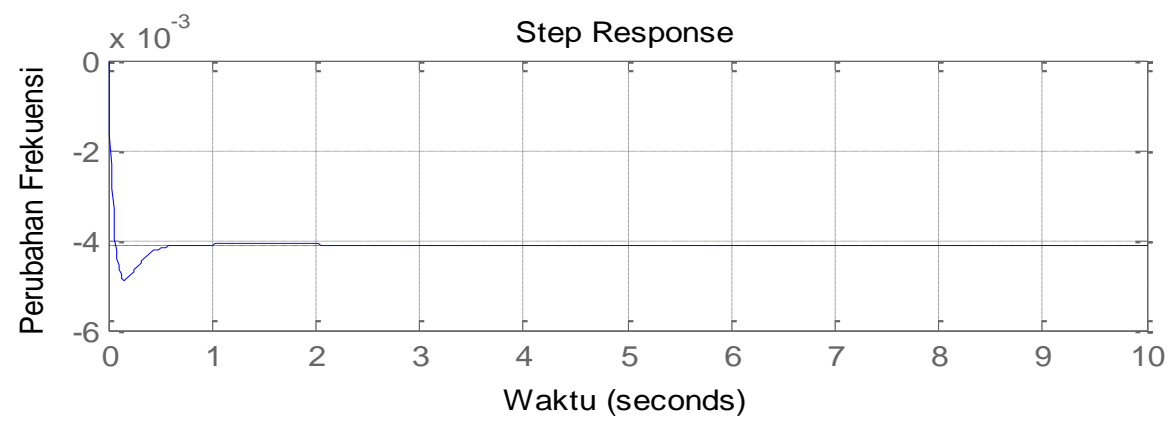

\section{Gambar 4. Tanggapan Peralihan Deviasi Frekuensi Untuk Tipe Non -} Reheat

Untuk analisa performansi dalam domain frekuensi diperlihatkan oleh nilai lebar pita. Untuk nilai lebar pita diperoleh dari diagram Magnitude Bode tanggapan deviasi frekuensi sistem tenaga listrik tipe Non Reheat dengan metoda Penempatan Kutub. Adapun nilai lebar pita diperlihatkan pada Tabel 9. Berikut.
Tabel 9. Hasil Analisa Performansi Dalam Domain Frekuensi

\begin{tabular}{|c|c|}
\hline Kriteria & Nilai \\
\hline Lebar Pita & $3.6959 \mathrm{rad} /$ detik \\
\hline
\end{tabular}

Untuk diagram Magnitude Bode tanggapan deviasi frekuensi sistem tenaga listrik tipe Non - Reheat dengan metoda Penempatan Kutub diperlihatkan pada Gambar 5. berikut

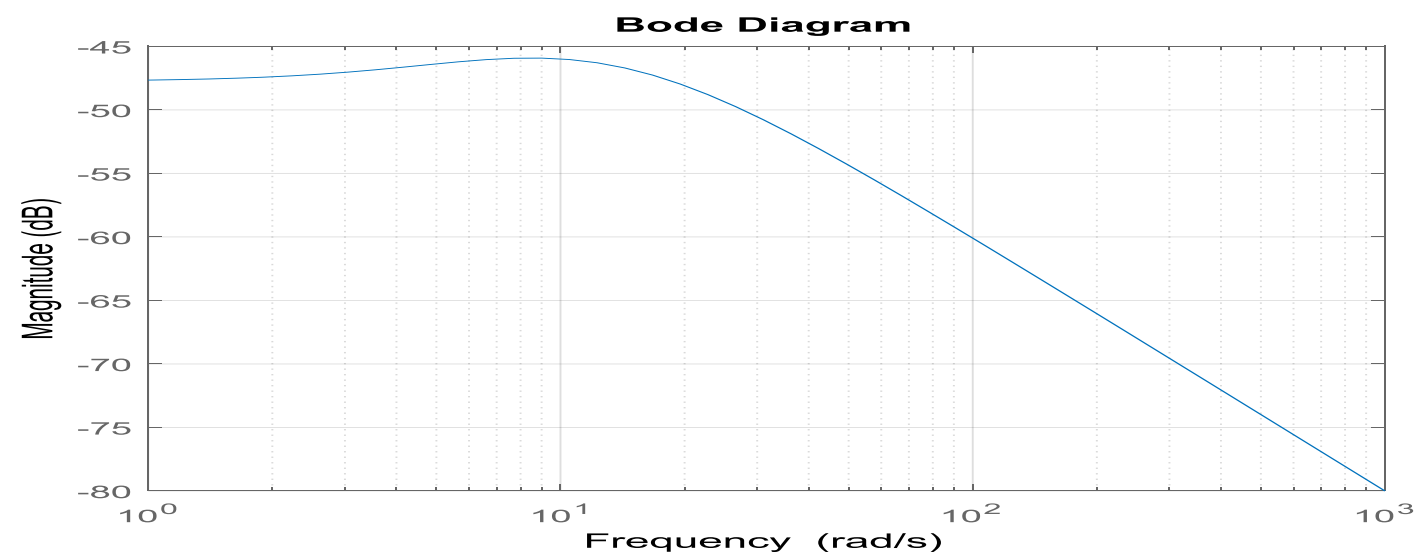

Gambar 5. Diagram Magnitude Bode Deviasi Frekuensi Sistem Tenaga Listrik Tipe Non - Reheat

Untuk analisa kestabilan deviasi frekuensi sistem tenaga listrik tipe Non - Reheat dengan metoda Penempatan Kutub dilakukan dengan menggunakan persamaan karakteristik. Adapun akar - akar dari persamaan karakteristik ini diperlihatkan pada Tabel 10. Berikut 
Tabel 10. Akar - Akar Persamaan Karakteristik

\begin{tabular}{|c|c|c|c|}
\hline $\begin{array}{c}\text { Akar - } \\
\text { Akar }\end{array}$ & $\begin{array}{l}\text { Redam } \\
\text { an }\end{array}$ & $\begin{array}{c}\text { Frekue } \\
\text { nsi }\end{array}$ & $\begin{array}{c}\text { Konsta } \\
\text { nta } \\
\text { Waktu }\end{array}$ \\
\hline $\begin{array}{l}- \\
2.000 \\
0+ \\
j 1.780 \\
0\end{array}$ & 1.0000 & 2.0000 & 0.5010 \\
\hline $\begin{array}{l}- \\
10.40 \\
00\end{array}$ & 1.0000 & $\begin{array}{c}10.400 \\
0\end{array}$ & 0.0963 \\
\hline $\begin{array}{l}- \\
11.80 \\
00\end{array}$ & 1.0000 & $\begin{array}{c}11.800 \\
0\end{array}$ & 0.0850 \\
\hline
\end{tabular}

Untuk analisa kekokohan tanggapan deviasi frekuensi sistem tenaga listrik tipe Non - Reheat dengan metoda Penempatan Kutub dilakukan dengan menggunakan nilai puncak sensitivitas dan nilai puncak sensitivitas komplementer. Adapun kedua nilai sensitivitas dari tanggapan deviasi frekuensi sistem tenaga listrik tipe Non - Reheat dengan metoda Penempatan Kutub ini diperlihatkan pada Tabel 11. berikut

Tabel 11. Hasil Analisa Performansi Dalam Domain Frekuensi

\begin{tabular}{|l|c|}
\hline \multicolumn{1}{|c|}{ Kriteria } & Nilai \\
\hline $\begin{array}{l}\text { Nilai Puncak Maksimum } \\
\text { Sensitivitas }\end{array}$ & 1.0049 \\
\hline $\begin{array}{l}\text { Nilai Puncak Maksimum } \\
\text { Sensitivitas } \\
\text { Komplementer }\end{array}$ & 0.0051 \\
\hline
\end{tabular}

Untuk hasil simulasi dengan metoda Penempatan Kutub menggunakan algoritma Bass Gura sudah memenuhi kriteria perancangan dimana waktu naik kurang dari 0.5000 detik, waktu keadaan mantap kurang dari 1.0000 detik, waktu puncak kurang dari 1.2500 , lewatan maksimum kurang dari $20.0000 \%$, nilai kesalahan keadaan mantap kurang dari 0.0500 , lebar pita kurang dari $15.0000 \mathrm{rad} /$ detik, nilai puncak maksimum kurang dari 2.0000 (6 dB) dan nilai puncak maksimum sensitivitas komplementer kurang dari $1.2500(2 \mathrm{~dB})$.

\section{KESIMPULAN}

Kesimpulan dari penelitian ini adalah tanggapan deviasi frekuensi sistem tenaga listrik tipe NonReheat dengan metoda Penempatan Kutub menggunakan algoritma Bass Gura memiliki nilai kesalahan keadaan mantap, kualitas dan kecepatan tanggapan, performansi dalam domain frekuensi, kestabilan dan performansi dalam domain waktu, domain frekuensi, kestabilan dan kekokohan yang lebih baik dibandingkan tanpa metoda Penempatan Kutub.

\section{DAFTAR PUSTAKA}

[1] Bevrani, Hassan. 2009, Robust Power System Frequncy Control, New York : Springer

[2] Shah, N. N., Chafekar, A. D., Mehta, D. N. \& Suthar, A. R., 2012, Automatic Load Frequency Control of Two Area Power System With Conventional dan Fuzzy Logic Control. IJRET, 1(3), pp. 343 347.

[3] Parmar, K. S., S. M. \& D. K., 2012, Improvement of Dynamic Performance of LFC of The Two Area Power System : An Analysis Using Matlab, International Journal of Computer Applications, 40(10), pp. $28-32$.

[4] Shanmugasundaram, V., A. R. \& T. J., 2012, Load Frequency Control Using Optimal PID 
Controller For Non - Reheat Thermal Power System With TCPS Uni, International Journal of Engineering and Advanced Technology (IJEAT) , 1(5), pp. $414-417$.

[5] Ikhe, A. \& A. K., 2013, Load Frequency Control For Interconnecte Power System Using Different Controllers, International Journal of Advances in Engineering \& Technology, pp. $85-89$.

[6] Laksono, H.D, M. Fajra, Danas, A \& Diafridho, 2016, Analisa Peralihan Deviasi Frekuensi Sistem Kendali Frekuensi Tenaga Listrik
Dengan Metoda Kendali Optimal, Jurnal Rekayasa Elektrika, 1(12).

[7] Skogestad, S. \& Postlethwaite, I, 1996 . Multivariable Feedback Control Analysis and Design. New York : McGraw Hill.

[8] Xue, Dingyu, Chen and D.P Atherton, 2007, Linear Feedback Control : Analysis and Design With Matlab, Philadelphia : SIAM.

[9] Laksono, H.D, 2014, Sistem Kendali, Jogjakarta: Graha IImu. 